\title{
Epidemiological analysis of Toxoplasma gondii infection in sheep in the state of Pernambuco, Brazil
}

\section{Análise epidemiológica da infecção por Toxoplasma gondii em ovinos no estado de Pernambuco, Brasil}

\author{
Érica Chaves Lúcio ${ }^{1}$; Juliana de Lima Pimentel²; \\ Saruanna Millena dos Santos Clemente ${ }^{3}$; Luenda Menezes Novaes Sá4; \\ Júnior Mário Baltazar Oliveira ${ }^{5}$; Pedro Paulo Feitosa Albuquerque ${ }^{6}$; \\ Rinaldo Aparecido Mota ${ }^{7}$; José Wilton Pinheiro Junior ${ }^{7 *}$
}

\begin{abstract}
The objective of this study was to determine the seroprevalence of anti-Toxoplasma gondii antibodies in sheep from the Agreste and Sertão regions of Pernambuco in Brazil and to analyze the risk factors associated with T. gondii infection. A total of 250 sheep from 14 sheep farms across the state of Pernambuco were used as samples. Indirect Fluorescent Antibody Test (IFAT) was used for the detection of anti-T. gondii antibodies, adopting a cut-off dilution of 1:64. In order to determine risk factors, farm owners were subjected to a questionnaire form enquiring about the aspects of operational hygiene and sanitary systems. Thirty-four of the 250 samples $(13.60 \%, 95 \% \mathrm{CI}=9.61 \%-18.48 \%)$ in the study were determined to be positive, and 10 out of $14(71.42 \%)$ of the sheep farms showed at least one seropositive animal. Titers for the 34 positive samples presented 8 samples at $64(23.53 \%), 3$ at $128(8.82 \%), 3$ at $256(8.82 \%), 13$ at $512(38.23 \%)$, and 7 at $1024(20.60 \%)$. After regression logistics, only the supply of silage $(\mathrm{p}=0.009 ; \mathrm{OR}=2.79$, CI $95 \%=1.29-6.0)$ was confirmed as a risk factor. The study was able to conclude that infection with $T$. gondii was prevalent in the sampled sheep farms in the state of Pernambuco, and that it was imperative to adopt preventive measures in order to effectively curb the identified risk factors.
\end{abstract}

Key words: Infection. Sheep. Pernambuco. Toxoplasmosis.

\section{Resumo}

Objetivou-se com este estudo determinar a prevalência de anticorpos anti-Toxoplasma gondii e analisar os fatores de riscos associados à infecção em ovinos no Agreste e Sertão do estado de Pernambuco. Para tal foram utilizadas 14 propriedades de ovinos totalizando 250 animais. Utilizou-se para a pesquisa

\footnotetext{
${ }^{1}$ Médica Veterinária, Discente de Doutorado, Programa de Pós-Graduação em Ciência Animal Tropical, Universidade Federal Rural de Pernambuco, UFRPE, Recife, Brasil. E-mail: erica.c.1@hotmail.com

2 Médica Veterinária, Discente de Mestrado, Programa de Pós-Graduação em Ciência Animal e Pastagem, UFRPE, Garanhuns, Brasil. E-mail: julianalp.vet@hotmail.com

${ }^{3}$ Médica Veterinária, Discente de Mestrado, Programa de Pós-Graduação em Ciência Animal Tropical, UFRPE, Dois Irmãos, Recife, Brasil. E-mail: saruannamillena@hotmail.com

${ }^{4}$ Médica Veterinária, Instituto Federal do Sertão Pernambucano, Campus Floresta, Floresta, Brasil. E-mail: luendalu@hotmail. com

${ }^{5}$ Médico Veterinário, Discente de Doutorado, Programa em Ciência Veterinária, UFRPE, Dois Irmãos, Recife, Brasil. E-mail: jrmariovet@yahoo.com.br

${ }^{6}$ Médico Veterinário, Laboratório de Patologia Veterinária, UFRPE, Dois Irmãos, Recife, Brasil. E-mail: ppfalbuquerque@gmail. com

7 Profs. Drs., Laboratório de Doenças Infecto-Contagiosas, Departamento de Medicina Veterinária, UFRPE, Dois Irmãos, Recife, Brasil. E-mail: rinaldo.mota@hotmail.com; wiltonjrufrpe@gmail.com

* Author for correspondence
} 
de anticorpos anti-Toxoplasma gondii a técnica de Imunofluorescência Indireta (RIFI), adotando-se ponto de corte de 1:64. No estudo dos fatores de risco foram aplicados questionários com perguntas objetivas sobre os aspectos do manejo higiênico-sanitário. Das 250 amostras analisadas 34 (13,60\%, IC $95 \%-9,61 \% ; 18,48 \%)$ foram positivas; $71,42 \%(10 / 14)$ das propriedades apresentaram ao menos um animal positivo. Em relação à titulação, observou-se que das 34 amostras positivas, oito apresentaram título de $64(23,53 \%)$; três títulos $128(8,82 \%)$; três títulos $256(8,82 \%)$; 13 títulos $512(38,23 \%)$; e sete $(20,60 \%)$ apresentaram título de 1024 . Após regressão logística apenas a variável fornecimento de silagem $(\mathrm{p}=0,009 ; \mathrm{OR}=2,79$ IC $95 \%=1,29-6,0)$ foi confirmada como fator de risco. Conclui-se que a infecção por Toxoplasma gondii está presente nas criações de ovinos na região estudada, sendo necessário à adoção de medidas preventivas e de controle que atuem nos fatores de risco identificados neste estudo.

Palavras-chave: Infecção. Ovelha. Pernambuco. Toxoplasmose.

\section{Introduction}

Toxoplasmosis, a parasitic disease caused by Toxoplasma gondii, is considered to be among the leading causes of abortions in several countries. Among domestic animals, it is largely known to impact the ovine species to a great extent (RAEGHI et al., 2011) with several studies indicating that this impact manifests itself as reproductive failures such as fetal malformations, placentitis, stillbirths, and abortions (BENKIRANE et al., 2015; DANEHCHIN et al., 2016).

Serological studies on the prevalence of anti- $T$. gondii antibodies show that toxoplasmosis is globally widespread among sheep, with seroprevalence values ranging between 5-87.5\% (RAMZAN et al., 2009; WU et al., 2011; HAMILTON et al., 2014; GAZZONIS et al., 2015; HUTCHINSON; SMITH, 2015). Similar serological studies conducted in Brazil have also reported seroprevalence values in sheep ranging between 3.7-35.3\% (MEIRELES et al., 2003; SILVA et al., 2003; PINHEIRO JÚNIOR et al., 2009; SOCCOL et al., 2009; PEREIRA et al., 2012; NUNES et al., 2015; SILVA et al., 2015).

Transmission of the parasite may occur through several methods: ingestion of oocysts via contaminated water and food, ingestion of tissues infected by bradyzoites, or via transplacental transfer. In case of sheep, infection usually occurs through the ingestion of oocysts that are present in food and contaminated soil (DUBEY; SHARMA, 1980). Transmission may also occur via contaminated semen during mating (LOPES, 2010) among naturally infected sheep (MORAES et al., 2010).

The presence of domestic cats is also considered to be one of the major contributing factors responsible for toxoplasmosis in sheep (DUBEY et al., 1986), since feline fecal matter is known to contaminate water, soil, and pasture sources with oocysts, aiding the natural cycle of the disease (COUTINHO et al., 1982; MANAIR et al., 1996; VAN DER PUIJE et al., 2000). Other factors such as spatial distribution of animals, climatic conditions, and farming and management practices are also known to influence the prevalence of $T$. gondii infection (HUTCHINSON; SMITH, 2015; LIU et al., 2015; YIN et al., 2015).

Given the zoonotic trait of this disease and the negative impact it imposes on sheep reproduction, the objective of this study was to evaluate the epidemiological aspects of $T$. gondii infection in sheep in Agreste and Sertão regions within the state of Pernambuco, Brazil.

\section{Materials and Methods}

\section{Ethics committee}

This study was approved by the Research Ethics Committee of the Universidade Federal Rural de Pernambuco with the license number 039/2012. 


\section{Sampling source}

The study was carried out on animals from 14 sheep farms located in the following municipalities of Agreste and Sertão in Pernambuco: Águas Belas (1), Arcoverde (1), Belém do São Francisco (1), Carnaubeira da Penha (1), Custódia (2), Floresta (1), Ibimirim (1), Itacuruba (1), Itaíba (2), Pedra (1), Sertânia (1), Tacaratu (1).

\section{Sampling}

In order to determine the sample size for the prevalence study, T. gondii infection in sheep was assumed to be at an expected prevalence rate of $35.3 \%$ (PEREIRA et al., 2012). Allowing for a $95 \%$ confidence interval and a statistical error of 5\% (THRUSFIELD, 2004), a minimum sampling size of 216 animals was calculated. Extending the age criterion to include all sheep over the age of one year allowed for a total of 250 samples to be collected.

For the selection of sheep farms, non-probabilistic sampling was used for convenience (COSTA NETO, 1977). In order to calculate the number of animals per property, the WIN EPISCOPE 2.0 software was used with the aforementioned parameters.

\section{Biological material}

Blood samples from each animal were obtained by venipuncture $(\sim 5 \mathrm{~mL})$, after antisepsis with $2 \%$ iodinated alcohol solution. The collected samples were stored in sterile tubes without adding anticoagulants to facilitate serum extraction at a later point. Each sample was then appropriately identified, packaged in isothermal boxes containing recyclable ice, and subsequently sent to the laboratory for processing. To extract serum, the samples were centrifuged for 10 minutes at $3000 \mathrm{~g}$. Once isolated, the serum was stored in polypropylene microtubes and frozen at $-20^{\circ} \mathrm{C}$ for further processing.

\section{Serological analysis}

Blood serum samples were subjected to Indirect Fluorescent Antibody Test (IFAT) for the detection of anti-T. gondii $\mathrm{IgG}$, considering a 1:64 dilution as the cut-off point. Tachyzoites of the $T$. gondii RH strain, maintained in mice, were used as antigens.

Previously extracted ovine serum samples were used as positive and negative controls for serological analysis. The reactions were considered positive when the tachyzoites showed total peripheral fluorescence and the serum samples were titrated until the highest positive dilution was obtained when subjected to IFAT.

\section{Elucidation of the prevalence map}

The georeferenced data was analyzed through the Quantum Geographic Information System (QGIS) program. The prevalence map of $T$. gondii infection with respect to the visited sheep farms was computed from the coordinates of the Universal Transverse Mercator (UTM) projection with the help of GPS (Global Positioning System) equipment.

\section{Statistical analysis}

Descriptive analysis was used to calculate the relative and absolute frequencies of the results obtained in the serological test. To identify the risk factors associated with $T$. gondii infection, a univariate analysis of the variables of interest was carried out using the Pearson chi-square test or Fisher's exact test, where appropriate. Logistic regression analysis was carried out using the Epi Info ${ }^{\mathrm{TM}}$ version 7.0, while considering the serological result as the dependent variable.

\section{Results and Discussion}

Of the 250 samples analyzed, 34 (13.60\%, 95\% $\mathrm{CI}=9.61 \%-18.48 \%$ ) were found to be positive for 
T. gondii. With respect to titration, it was observed that out of the 34 positive samples, 8 presented a titer value of $64(23.53 \%), 3$ presented a titer value of $128(8.82 \%), 3$ presented a titer value of 256 $(8.82 \%), 13$ presented a titer value of $512(38.23 \%)$, and 7 presented a titer value of 1024 (20.60\%).
Moreover, it was observed that 10 out of the 14 sheep farms $(71.42 \%)$ showed at least one seropositive animal. Data obtained on the prevalence of $T$. gondii infection among sheep from the sampled farms is shown in Table 1, and a map demonstrating the prevalence of infection is shown in Figure 1. Analysis of the municipality distribution showed an infection rate of $71.43 \%$ in the city of Pedra (15/21).

Table 1. Prevalence of $T$. gondii infection in sheep in the sampled sheep farms in Agreste and Sertão, state of Pernambuco, Brazil.

\begin{tabular}{ccc}
\hline Sheep farms & Absolute frequency & Relative frequency (\%) \\
\hline $\mathrm{A}$ & $2 / 9$ & 22.22 \\
$\mathrm{~B}$ & $1 / 12$ & 8.33 \\
$\mathrm{C}$ & $0 / 15$ & - \\
$\mathrm{D}$ & $2 / 21$ & 9.52 \\
$\mathrm{E}$ & $3 / 19$ & 15.79 \\
$\mathrm{~F}$ & $3 / 19$ & 15.79 \\
$\mathrm{G}$ & $2 / 12$ & 16.67 \\
$\mathrm{H}$ & $15 / 21$ & 71.43 \\
$\mathrm{I}$ & $0 / 21$ & - \\
$\mathrm{J}$ & $2 / 20$ & 10.00 \\
$\mathrm{~K}$ & $2 / 22$ & 9.09 \\
$\mathrm{~L}$ & $0 / 20$ & - \\
$\mathrm{M}$ & $2 / 20$ & 10.00 \\
$\mathrm{~N}$ & $0 / 19$ & - \\
\hline
\end{tabular}

Figure 1. Spatial distribution of T. gondii infection in sheep from Agreste and Sertão, state of Pernambuco, Brazil.

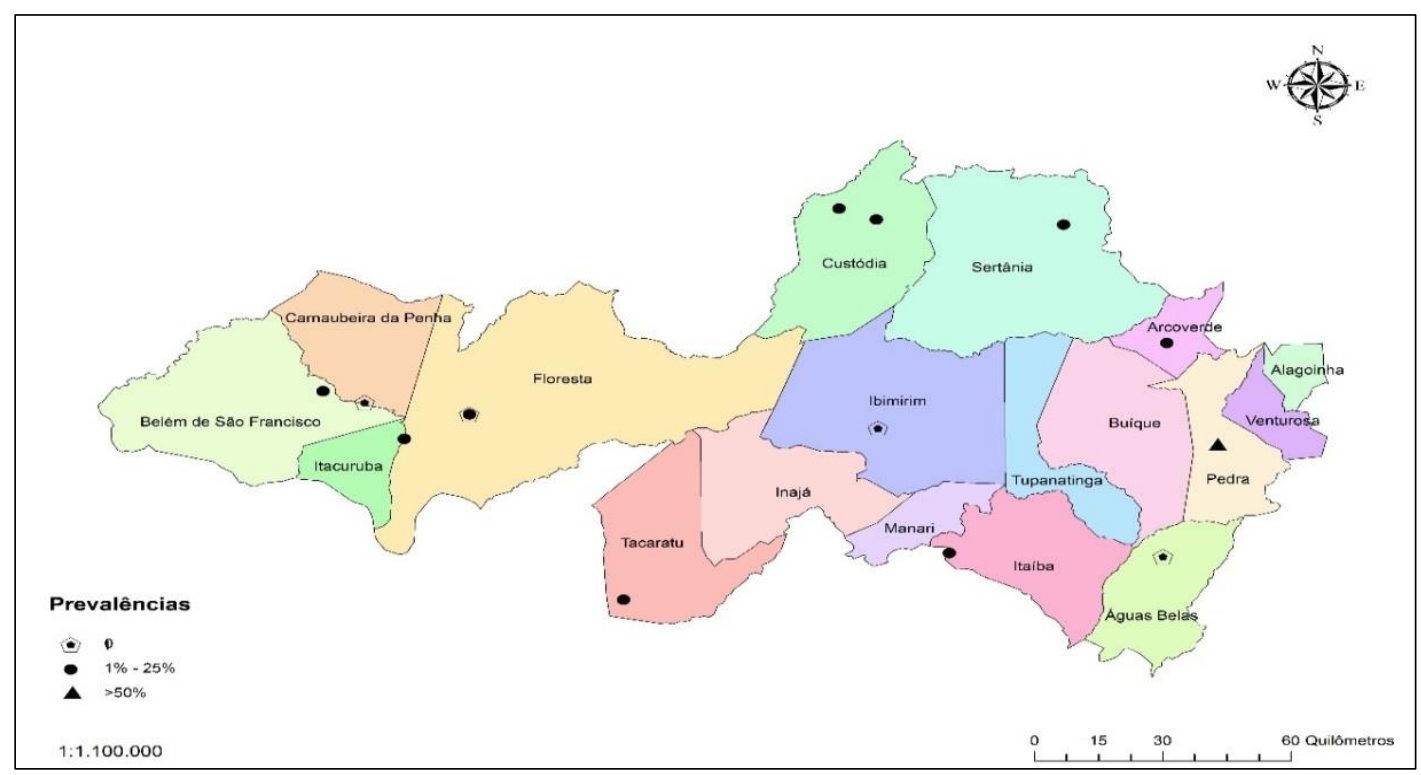


Although production animals like sheep were found to be more susceptible to infection than other species (MILLAR et al., 2008), serological studies have confirmed the distribution of $T$. gondii infection in sheep with variable percentages (TENTER et al., 2000). The prevalence of seropositive animals found in this study (13.60\%) was lower than the results found in other Brazilian states (LANGONI et al., 1999; PINHEIRO JÚNIOR et al., 2009). A previous study pertaining to other regions of Pernambuco showed similar results, with $16.90 \%$ of sheep seropositive for $T$. gondii infection (SILVA et al., 2003). These variations can be attributed to factors such as sample plan, serological method used, age of the animals, edaphoclimatic characteristics of the studied regions (DUBEY; BEATTIE, 1988; VELASCO-CASTREJÓN et al., 1992; HUTCHINSON; SMITH, 2015), and management of the study population (DUBEY, 1990).

Furthermore, it may be noted that possible variations were observed in antibody titer values because samples may present low titers of antibodies during initial and chronic stages of $T$. gondii infection (BARBOSA et al., 2003). In experimental studies, anti-T. gondii IgG antibodies were detected in the serum of infected sheep from the $7^{\text {th }}$ day post inoculation (MORAES et al., 2010), and the concentrations of these immunoglobulins remained elevated for a long period of time (CAMARGO et al., 1995). Unfortunately, it was not possible to accurately determine the stage of infection of the sheep in the present study. However, performing a new serum collection within an interval of four weeks in order to determine a four-fold increase in antibody levels in the second sample would indicate the possibility of an acute infection (DUBEY; LINDSAY, 2006).

Analysis of the data regarding the prevalence of infection within the sheep farms reported a variation range between $8.33-71.42 \%$. This difference may be attributed to the breeding systems employed and sanitary management practices adopted at the respective farms. The number of farms with seropositive animals was also found to be high (10/14), thus confirming that $T$. gondii infection was widespread in the sampled region.

Univariate analysis of the risk factors of $T$. gondii infection (Table 2) successfully associated the presence of infection with reproductive problems in the herd such as stillborn mortality and weak offspring. These reproductive problems cause economic losses for producers. In Uruguay, 1.4$3.9 \%$ of the offspring were reported to be lost owing to toxoplasmosis during gestation in sheep, which caused an estimated loss of US \$1.4-4.7 million (FREYRE et al., 1999). GARCIA-VASQUEZ et al. (1993) have pointed out that the economic losses caused by toxoplasmosis can be of particular concern to the small-scale farmer.

Although no statistical significance in serology results was observed between the sex of the animals ( $p=0.396)$, a higher prevalence of infection was observed in females, thereby corroborating previous studies (VAN DER PUIJE et al., 2000; SILVA et al. 2003). Infection in females was observed to occur more frequently possibly due to immunosuppression during gestation and lactation (UZÊDA et al., 2004). In general, females were more likely to be predisposed to infection due to hormonal, physiological and management differences in comparison to males (VAN DER PUIJE et al., 2000).

Contrary to other study findings (VESCO et al., 2007; LIU et al., 2015), no association was found between the presence of cats and the occurrence of infection in sheep $(p=0.431)$ in the present study. However, this may have occurred because of the sampling design used. Domestic cats have been established as definitive hosts of $T$. gondii and as an important factor driving infection in production animals, since oocysts eliminated in the feces of these animals is known to contaminate the environment. 
Table 2. Univariate analysis of risk factors associated with T. gondii infection in sheep in Agreste and Sertão, state of Pernambuco, Brazil.

\begin{tabular}{|c|c|c|c|c|}
\hline Variables & $\mathbf{N}$ & $\begin{array}{c}\text { Reagent } \\
\text { n (\%) }\end{array}$ & OR (CI 95\%) & P value \\
\hline \multicolumn{5}{|l|}{ Sex } \\
\hline Male & 45 & $5(11.1)$ & - & 0.396 \\
\hline Female & 205 & $29(14.1)$ & $1.31(0.46 ; 4.62)$ & \\
\hline \multicolumn{5}{|l|}{ Presence of cats } \\
\hline Presence & 60 & $9(15.0)$ & - & 0.431 \\
\hline Absence & 190 & $25(13.2)$ & $1.16(0.44 ; 2.78)$ & \\
\hline \multicolumn{5}{|l|}{ Creation system } \\
\hline Extensive & 72 & $16(22.2)$ & - & $0.011 *$ \\
\hline Semi-intensive & 178 & $18(10.1)$ & $2.53(1.12 ; 5.66)$ & \\
\hline \multicolumn{5}{|l|}{ Reproduction } \\
\hline Natural mount & 230 & $32(13.9)$ & - & 0.469 \\
\hline Artificial insemination & 20 & $2(10.0)$ & $1.45(0.32 ; 13.50)$ & \\
\hline \multicolumn{5}{|l|}{ Surface water } \\
\hline Presence & 134 & $21(15.7)$ & - & 0.200 \\
\hline Absence & 116 & $13(11.2)$ & $1.47(0.66 ; 3.37)$ & \\
\hline \multicolumn{5}{|l|}{ Silage } \\
\hline Yes & 101 & $22(21.8 \%)$ & - & $0.001 *$ \\
\hline No & 149 & $12(8.1 \%)$ & $3.17(1.41 ; 7.42)$ & \\
\hline
\end{tabular}

$\mathrm{N}$ - Number of corresponding variables, OR - Odds Ratio, CI - Confidence interval, * - Significant association at 5\%.

No significant association between the presence of surface water and serology results $(p=0.200)$ was observed, but the presence of contaminated surface water could act as a transmission route for T. gondii oocysts and increase the risk of infection of the animals (VESCO et al., 2007).

The silage supply was confirmed as a risk factor upon logistic regression analysis (Table 3 ) owing to prolonged and improper storage practices. During visits to the farms, it was observed that cats had free access to the silage storage areas. Tzanidakis et al. (2012) have suggested that food storage areas may increase the likelihood of intermediate hosts such as rodents and that in order to control their population, owners are more likely to introduce cats on site.
With regard to reproductive problems, a significantassociation was observed for the following variables: stillbirth $(\mathrm{p}=0.000)$ and low birth weight $(p=0.019)$. In addition to the reproductive issues that toxoplasmosis can cause in sheep, risk to public health is also a major cause for concern as this disease exhibits zoonotic traits. This poses a serious global health issue, especially for high-risk groups such as pregnant women (SHAAPAN, 2016), human immunodeficiency virus (HIV) patients and transplant patients (SAADATNIA; GOLKAR, 2012; GEBREMEDHIN; TADESSE, 2015; SILVA et al., 2016). In these groups, the likelihood of consumption of poorly-cooked meat from infected animals may promote infection risks (ARMAND et al., 2015; SHAAPAN, 2016). 
Table 3. Logistic regression analysis of risk factors associated with T. gondii infection in sheep in Agreste and Sertão, state of Pernambuco, Brazil.

\begin{tabular}{lccc}
\hline Variables & P value & OR & CI 95\% \\
\hline Supply of silage & 0.009 & 2.79 & $1.29-6.00$ \\
\hline N- Number of variables, OR - Odds Ratio, CI - Confidence interval, * - Significant association at $5 \%$ &
\end{tabular}

$\mathrm{N}$ - Number of variables, OR - Odds Ratio, CI - Confidence interval, * - Significant association at 5\%.

In light of the obtained results, it was concluded that $T$. gondii infection was widely distributed in the sampled sheep farms. This study was also the first to report this infection in sheep in the Sertão region in the state of Pernambuco, Brazil. Efforts to obtain further knowledge regarding epidemiology of the infection is of fundamental importance so that responsible organizations may be able to implement prophylactic measures and avoid dissemination of the parasite among animal herds, thereby preventing economic losses and guaranteeing viable sheep production.

\section{Acknowledgements}

The authors gratefully acknowledge CNPq for the productivity grant awarded in support of this work (Proc. No. 306015/2012-9).

\section{References}

ARMAND, B.; SOLHJOO, K.; SHABANIKORDSHOOLI, M.; DAVAMI, M. H.; SADEGHI, M. Toxoplasma infection in sheep from south of Iran monitored by serological and molecular methods; risk assessment to meat consumers. Veterinary World, Wankaner, v. 9, n. 8, p. 850-855, 2015.

BARBOSA, M. V. F.; GUIMARÃES, J. E.; ALMEIDA, M. A. O.; GONDIM, L. F. P.; REGIS, G. B. Frequency of IgG antibodies against-Toxoplasma gondii in sera of stray dogs in the city of Salvador-Bahia, Brazil. Brazilian Journal of Veterinary Research and Animal Science, São Paulo, v. 40, n. 6, p. 457-465, 2003.

BENKIRANE, A.; ESSAMKAOUI, S.; EL IDRISSI, A.; LUCCHESE, L.; NATALE, A. A sero-survey of major infectious causes of abortion in small ruminants in Morocco. Veterinaria Italiana, Teramo, v. 51, n. 1, p. 25-30, 2015.
CAMARGO, M. E. Alguns aspectos atuais do diagnóstico de laboratório da toxoplasmose. Anais da Academia Nacional de Medicina, Rio de Janeiro, v. 155, n. 4, p. 236-239, 1995.

COSTA NETO, P. L. O. Estatística. São Paulo: Ed. Edgar Blücher, 1977. $264 \mathrm{p}$.

COUTINHO, S. G.; LOBO, R.; DUTRA, G. Isolation of Toxoplasma from the soil during an outbreak of toxoplasmosis in a rural area in Brazil. The Journal of Parasitology, Lawrence, v. 68, n. 5, p. 866-868, 1982.

DANEHCHIN, L.; RAZMI, G.; NAGHIBI, A. Isolation and Genotyping of Toxoplasma gondii Strains in Ovine Aborted Fetuses in Khorasan Razavi Province, Iran. The Korean Journal of Parasitology, Seoul, v. 54, n. 1, p. 1520, 2016.

DUBEY, J. P. Diagnosis of livestock abortion due to Toxoplasma gondii. Ames: Ed. Iowa State University Press Ames, 1990. 260 p.

DUBEY, J. P.; BEATTIE, C. P. Toxoplasmosis of animals and man. Boca Raton: CRC Press, 1988. 220p.

DUBEY, J. P.; LINDSAY, D. S. Neosporosis, Toxoplasmosis, and Sarcocystosis in Ruminants. Veterinary Clinics of North America - Food Animal Practice, Philadelphia v. 22, n. 3, p. 645-671, 2006.

DUBEY, J. P.; MILLER, S.; POWELL, E. C.; ANDERSON, W. R. Epizootiologic investigations on a sheep farm with Toxoplasma gondii-induced abortions. Journal of the American Veterinary Medical Association, Ithaca, v. 188, n. 2, p. 155-158, 1986.

DUBEY, J. P.; SHARMA, S. P. Parasitemia and tissue infection in sheep fed Toxoplasma gondii oocysts. The Journal of Parasitology, Lawrence, v. 66, n. 1, p. 111114, 1980.

FREYRE, A.; BONINO, J.; FALCÓN, J.; CASTELLS, D.; CORREA, O.; CASARETTO, A. The incidence and economic significance of ovine toxoplasmosis in Uruguay. Veterinary Parasitology, Chichester, v. 81, n. 1, p. 85-88, 1999. 
GARCÍA-VÁZQUEZ， Z.; ROSARIO-CRUS， R.; DIAZ-GARCIA, G.; HERNANDEZ-BAUMGARTEN, O. Seroprevalence of Toxoplasma gondii infection in cattle, swine and goats in four mexican states. Preventive Veterinary Medicine, Amsterdam, v. 17, n. 1, p. 127-132, 1993.

GAZZONIS, A. L.; VERONESI, F.; DI CERBO, A. R.; ZANZANI, S. A.; MOLINERI, G.; MORETTA, I.; MORETTI, A.; FIORETTI, D. P.; MANFREDI, M. T. Toxoplasma gondii in small ruminants in Northern Italy prevalence and risk factors. Annals of Agricultural and Environmental Medicine, Lublin, v. 22, n. 1, p. 62-68, 2015.

GEBREMEDHIN, E. Z.; TADESSE, G. A meta-analysis of the prevalence of Toxoplasma gondii in animals and humans in Ethiopia. Parasites \& Vectors, Londres, v. 8, n. 1, p. 1-9, 2015.

HAMILTON, C. M.; KATZER, F.; INNES, E. A.; KELLY, P. J. Seroprevalence of Toxoplasma gondii in small ruminants from four Caribbean islands. Parasites \& Vectors, Londres, v. 7, n. 1, p. 449-452, 2014.

HUTCHINSON, J. P.; SMITH, P. Seropositivity to Toxoplasma infection in sheep samples submitted to Animal and Plant Health Agency laboratories between 2005 and 2012. The Veterinary Record, Londres, v. 176, n. 22, p. 573-573, 2015.

LANGONI, H.; ROSA C.; MARINHO M. Inquérito epidemiológico para a toxoplasmose em ovinos no Estado de São Paulo, Brasil. O Biológico, São Paulo, v. 61, n. 1, p. 35-39, 1999.

LIU, Z. K.; LI, J. Y.; PAN, H. Seroprevalence and risk factors of Toxoplasma gondii and Neospora caninum infections in small ruminants in China. Preventive Veterinary Medicine, Amsterdam, v. 118, n. 4, p. 488492, 2015.

LOPES, W. D. Z. Transmissão sexual de Toxoplasma gondii (Nicolle \& Manceaux, 1909) em ovinos (Ovis aries). 2010. Tese (Doutorado em Medicina Veterinária) Universidade Estadual Paulista. Campus de Jaboticabal, Jaboticabal.

MANAIR, R. C.; DE LA CRUZ, C.; ASENSIO, A.; DOMÍNGUEZ, L; VÁZQUEZ-BOLAND, J. A. Prevalence of agglutinating antibodies to Toxoplasma gondii in small ruminants of the Madrid region, Spain, and identification of factors influencing seropositivity by $\mathrm{mu}$ multivariate analysis. Veterinary Research Communications, Amsterdam, v. 20, n. 2, p. 153-159, 1996.

MEIRELES, L. R.; GALISTEU JÚNIOR, A. J.; ANDRADE JÚNIOR, H. F. Serological survey of antibodies to Toxoplasma gondii in food animals from São Paulo state. Brazilian Journal of Veterinary Research and Animal Science, São Paulo, v. 40, n. 4, p. 267-271. 2003.

MILLAR, P. R.; SOBREIRO L. G.; BONNA, I. C. F.; AMENDOEIRA, M. R. R. A importância dos animais de produção na infecção por Toxoplasma gondii no Brasil. Semina: Ciências Agrárias, Londrina, v. 29, n. 3, p. 693706, 2008.

MORAES, E. P. B. X. Detecção de Toxoplasma gondii no sêmen de ovinos naturalmente infectados. Pesquisa Veterinária Brasileira, Rio de Janeiro, v. 30, n. 11, p. 915-917, 2010.

NUNES, A. C. B. T.; SILVA, E. M. V.; OLIVEIRA, J. A.; YAMASAKI, E. M.; KIM, P. C. P.; ALMEIDA. J. C.; NUNES, K. B.; MOTA, R. A. Application of different techniques to detect Toxoplasma gondii in slaughtered sheep for human consumption. Brazilian Journal of Veterinary Parasitology, São Paulo, v. 24, n. 4, p. 416421, 2015.

PEREIRA, M. D. F.; PEIXOTO, R. D. M.; LANGONI, H.; GRECA JUNIOR, H.; AZEVEDO, S. S. D.; PORTO, W. J. N.; NASCIMENTO, W. J.; MEDEIROS, E. S.; MOTA, R. A. Fatores de risco associados à infecção por Toxoplasma gondii em ovinos e caprinos no estado de Pernambuco. Pesquisa Veterinária Brasileira, Rio de Janeiro, v. 32, n. 2, p. 140-146, 2012.

PINHEIRO JÚNIOR, J. W.; MOTA, R. A.; FONSECA OLIVEIRA, A. A.; FARIA, E. B.; GONDIM, L. F. P.; SILVA, A. V.; ANDERLINI, G. A. Prevalence and risk factors associated to infection by Toxoplasma gondii in ovine in the state of Alagoas, Brazil. Parasitology Research, Berlin, v. 105, n. 3, p. 709-715, 2009.

RAEGHI, S.; AKABERI, A.; SEDEGHI, S. Seroprevalence of Toxoplasma gondii in sheep, cattle and horses in Urmia North-West of Iran. Iranian Journal of Parasitology, Tehran, v. 6, n. 4, p. 90-94, 2011.

RAMZAN, M.; AKHTAR, M.; MUHAMMAD, F.; HUSSAIN, I.; HISZCZYŃSKA-SAWICKA, E.; HAQ, A. U.; MAHMOOD, M. S.; HAFEEZ, M. A. Seroprevalence of Toxoplasma gondii in sheep and goats in Rahim Yar Khan (Punjab), Pakistan. Tropical Animal Health and Production, Edinburgh, v. 41, n. 7, p. 12251229, 2009.

SAADATNIA, G.; GOLKAR, M. A review on human toxoplasmosis. Scandinavian Journal of Infectious Diseases, Stockholm, v. 44, n. 11, p. 805-814, 2012.

SHAAPAN, R. M. The common zoonotic protozoal diseases causing abortion. Journal of Parasitic Diseases, New Delhi, v. 40, n. 4, p. 1116-1129, 2016. 
SILVA, A. V.; CUNHA, E. L. P.; MEIRELES, L. R.; GOTTSCHALK, S.; MOTA, R. A.; LANGONI, H. Toxoplasmose em ovinos e caprinos: estudo soroepidemiológico em duas regiões do Estado de Pernambuco, Brasil. Ciência Rural, Santa Maria, v. 33, n. 1, p. 115-119, 2003.

SILVA, I. B.; ANDRADE BATISTA, T. P.; MARTINES, R. B.; KANAMURA, C. T.; FERREIRA, I. M. R.; VIDAL, J. E.; PEREIRA-CHIOCCOLA, V. L. Genotyping of Toxoplasma gondii: DNA extraction from formalin-fixed paraffin-embedded autopsy tissues from AIDS patients who died by severe disseminated toxoplasmosis. Experimental Parasitology, New York, v. 165, n. 1, p. 16-21, 2016.

SILVA, J. G.; ALVES, B. H. L.; MELO, R. P. B.; KIM, P. C. P.; SOUZA NETO, O. L.; BEZERRA, M. J. G.; SÁ, S. G.; MOTA, R. A. Occurrence of anti-Toxoplasma gondii antibodies and parasite DNA in raw milk of sheep and goats of local breeds reared in Northeastern Brazil. Acta Tropica, Basel, v. 142, n. 1, p. 145-148, 2015.

SOCCOL, V. T.; CASTRO, E. A.; GAZDA, T. L.; GARCIA, G.; RICHARTZ, R. R. T. B.; DITTRICH, R. L. Ocorrência de anticorpos anti-Toxoplasma gondii em ovinos das áreas urbanas e periurbanas de Curitiba, Paraná. Revista Brasileira de Parasitologia Veterinária, São Paulo, v. 8, n. 1, p. 69-70, 2009.

TENTER, A. M.; HECKEROTH, A. R.; WEISS, L. M. Toxoplasma gondii: from animals to humans. International Journal for Parasitology, Oxford, v. 30, n. 12, p. 1217-1258, 2000.

THRUSFIELD, M. V. Epidemiologia veterinária. São Paulo: Ed. Roca, 2004. 556 p.

TZANIDAKIS, N.; MAKSIMOV, P.; CONRATHS, F. J.; KIOSSIS, E.; BROZOS, C.; SOTIRAKI, S.; SCHARES, G. Toxoplasma gondii in sheep and goats: seroprevalence and potential risk factors under dairy husbandry practices. Veterinary Parasitology, Amsterdam, v. 190, n. 3, p. 340348, 2012.
UZÊDA, R. S.; FERNÁNDEZ, S. Y.; JESUS, E. E. V.; PINHEIRO, A. M.; AYRES, M. C. C.; SPINOLA, S.; BARBOSA JÚNIOR, H. V.; ALMEIDA, M. A. O. Fatores relacionados à presença de anticorpos IgG antiToxoplasma gondii em caprinos leiteiros do Estado da Bahia. Revista Brasileira de Saúde e Produção Animal, Salvador, v. 5, n. 1, p. 1-8, 2004.

VAN DER PUIJE, W. N. A.; BOSOMPEM, K. M.; CANACOO, E. A.; WASTLING, J. M.; AKANMORI, B. D. The prevalence of anti-Toxoplasma gondii antibodies in Ghanaian sheep and goats, Memorial Institute, Acta Tropica, Basel, v. 76, n. 1, p. 21-26, 2000.

VELASCO-CASTREJÓN, O.; SALVATIERRA-IZABA, B.; VALDESPINO, J. L.; SEDANO-LARA, A. M.; GALINDO-VIRGEN, S.; MAGOS, C.; TAPIA, C. R.; GUTIERREZ, G.; SEPULVEDA, J. Seroepidemiología de latoxoplasmosis em México. Salud pública de México, Cuernavaca, v. 34, n. 1, p. 222-229, 1992.

VESCO, G.; BUFFOLANO, W.; LA CHIUSA, S.; MANCUSO, G.; CARACAPPA, S.; CHIANCA, A.; VILLARI, S.; CURRÒ, V.; LIGA, F.; PETERSEN, E. Toxoplasma gondii infections in sheep in Sicily, southern Italy. Veterinary Parasitology, Amsterdam, v. 146, n. 1, p. 3-8, 2007.

WU, S. M.; DANBA, C.; HUANG, S. Y.; ZHANG, D. L.; CHEN, J.; GONG, G.; XU, M. J.; YUAN, Z. G.; ZHU, X. Q. Seroprevalence of Toxoplasma gondii infection in Tibetan sheep in Tibet, China. The Journal of Parasitology, Lawrence, v. 97, n. 6, p. 1188-1189, 2011.

YIN, M. Y.; WANG, J. L.; HUANG, S. Y.; QIN, S. Y.; ZHOU, D. H.; LIU, G. X.; TAN, Q. D.; ZHU, X. Q. Seroprevalence and risk factors of Toxoplasma gondii in Tibetan Sheep in Gansu province, Northwestern China. $B M C$ Veterinary Research, Londres, v. 11, n. 41, p. 1-5, 2015. 
